\title{
Pengaruh Variasi Warna Pada Fly Grill Terhadap Kepadatan Lalat (Studi di Rumah Pemotongan Ayam Pasar Terban Kota Yogyakarta)
}

\author{
Vinanda Yurika Emerty ${ }^{1}$, Surahma Asti Mulasari ${ }^{*}$ \\ ${ }^{1}$ Fakultas Kesehatan Masyarakat, Universitas Ahmad Dahlan,Yogjakarta \\ *Corresponding Author: surahma.mulasari@ikm.uad.ac.id
}

Info Artikel : Diterima 11 April 2019 ; Disetujui 11 Desember 2019; Publikasi 1 April 2020

\begin{abstract}
ABSTRAK
Latar Belakang: lalat salah satu vektor mekanik karena menyebabkan penyakit secara tidak langsung. Semua bagian lalat berperan sebagai alat penular penyakit, dari badan, bulu tangan dan kaki, feses, serta muntahannya. Fly Grill adakah salah satu teknik pengendalian lalat dengan melihat kepadatan lalat di suatu tempat. Alat ini dapat diberikan variasi warna karena serangga memiliki ketertarikan kepada gelombang warna yang berbeda. Penelitian ini dilakukan untuk mengetahui perbedaan kepadatan lalat pada variasi warna pada Fly Grill.

Metode: Penelitian ini adalah kuasi eksperimen. Perlakuan dengan Fly Grill yang berbeda warna (kuning, biru, hijau, putih) dan kontrol (bambu tanpa diberi cat). Pengukuran pada tiga titik ukur $(0,1,2 \mathrm{~m}$ dari tempat pemotongan). Data yang diperoleh dianalisis menggunkan uji ANOVA dengan derajat kesalahan $\alpha 0,05$. dilanjutkan dengan uji Post hoc Benferroni.

Hasil: Hasil penelitian menunjukkan ada perbedaan signifikan rata rata jumlah lalat yang terperangkap pada $F l y$ Grill yang berbeda warna. Antara Fly Grill warna kuning- biru diperoleh nilai p value $0,030<\alpha(0,05)$ artinya terdapat perbedaan yang bermakna antara Fly Grill warna kuning dan biru. Sedangkan antara Fly Grill warna biru- putih diperoleh nilai p value $0,037<\alpha(0,05)$ artinya terdapat perbedaan yang bermakna antara Fly Grill warna biru dan putih.

Simpulan: Ada perbedaan nyara kepadatan lalat pada Fly Grill warna Putih, Kuning, Biru, Hijau, dan Kontrol. Terdapat perbedaan yang bermakna pada kepatan lalat pada Fly Grill warna kuning-biru dan Fly Grill warna biru-putih. Warna Kuning paling tinggi kepadatan lalatnya sedangkan warna biru warna yang paling rendah kepadatan lalatnya.
\end{abstract}

Kata kunci: Lalat; kepadatan; vector; Fly Grill; rumah pemotongan ayam.

\section{ABSTRACT}

Title: The effects of colour variation on fly grill toward the density of flies: a case study in the chicken abattoir of Terban traditional market, Yogyakarta

Background: Fly is one mechanic vector because it causes disease indirectly. All parts of fly play role in transferring disease, from body, feathers of hands and feet, feces, and vomiting. One technique to understand fly density in one location is to use Fly Grill. This tool can be given varying colors because this insect has attraction to different color waves. A research was done to understand difference of fly densities in various colors of Fly Grill.

Method: The research in this study was quasi experimental. The data were collected by using five Fly Grills with different colors (yellow, blue, green, white and control), conducted in three measuring points $(0,1$, and $2 \mathrm{~m})$ from Chicken slaughterhouse. The collected data were analyzed by using ANOVA (Analysis of Variance) with error degree $\alpha=0.05$ followed by the Post hoc Benferroni test.

Results: The result was a significant difference in the average number of flies trapped on different colored Fly Grills. Between yellow and blue Fly Grills indicated that $p$ value $0.30<\alpha(0.05)$, that means had significant difference between the yellow and blue Fly Grills, and blue and white Fly Grills indicated that p value $0.037<$ $\alpha(0.05)$ that means had significant difference between blue and white Fly Grills. 
Conclusions: There was a difference in the density of flies on the Fly Grill colors White, Yellow, Blue, Green, and Control There was difference of fly densities in yellow-blue Fly Grills and blue-white Fly Grills in the Chicken slaughterhouse (RPA) in Terban Market, Yogyakarta City. Yellow has the highest density of flies while blue has the lowest density of flies

Keywords: fly; density; vector; Fly Gril; chicken slaughterhouse

\section{PENDAHULUAN}

Tempat-tempat umum seperti pasar sangat banyak dikunjungi masyarakat karena merupakan salah satu tempat yang menyediakan pasokan kebutuhan pokok sehari-hari. Salah satunya adalah rumah pemotongan ayam (RPA) yang terdapat di kawasan pasar merupakan tempat penyedia jasa pemotongan ayam yang dibutuhkan masyarakat. Tempat pemotongan ayam di Indonesia selama ini masih dipandang kurang baik, karena kekumuhan dan kekotoran yang diperlihatkannya. Buruknya keadaan lingkungan dapat berpengaruh terhadap kesehatan masyarakat di sekitarnya. Hal ini disebabkan karena banyaknya hewan pengerat dan vektor penyakit seperti lalat dan tikus yang berkeliaran disekitar tempat tersebut.

Peraturan Pemerintah Nomor 66 Tahun 2014 pasal 8 ayat 1 yaitu berisi Standar Baku Mutu Kesehatan Lingkungan dan Persyaratan Kesehatan ditetapkan pada media lingkungan yang meliputi: air, udara, tanah, pangan, sarana dan bangunan, vektor serta binatang pembawa penyakit. Serta ayat 2 yang berbunyi lingkungan sehat mencakup lingkungan pemukiman, tempat kerja, tempat rekreasi, serta tempat fasilitas umum. ${ }^{1}$ Rumah pemotongan ayam atau pasar unggas merupakan salah satu lingkungan yang banyak ditemukan vector pernyakit. Tempat ini sangat mendukung untuk kelangsungan hidup lalat karena merupakan daerah terbuka yang terdapat banyak kotoran, sampah, cairan darah dari hasil pemotongan unggas, serta bulu-bulu unggas yang dapat menarik dan mempercepat perkembangbiakan lalat. Lalat akan meletakkan telur di tempat yang menjadi sumber makanan, jenis lalat tersebut biasanya jenis Musca domestica atau biasa disebut lalat rumah. ${ }^{2}$

Apabila tidak dilakukan pengelolaan dan/atau pengolahan pada limbah rumah pemotongan hewan maka limbah tersebut menjadi media pertumbuhan dan perkembangan mikroba sehingga limbah mengalami pembusukan. ${ }^{3}$ Sampah yang telah mengalami penimbunan dan pembusukan dapat dimanfaatkan oleh lalat sebagai sarang dalam proses perkembangbiakannya. ${ }^{4}$

Jenis lalat yang banyak merugikan manusia adalah Lalat rumah (Musca domestica), lalat hijau (Calliphora megacephala dan Lucilia sp.), lalat biru (Calliphora vomituria), dan lalat latrine (Fannia canicularis). Infestasi lalat rumah dan lalat hijau berdampak negatif terhadap kesehatan manusia di seluruh dunia. ${ }^{5}$ Lalat berperan dalam penularan patogen penyakit pada manusia. Lalat juga berperan sebagai vektor dalam kontaminasi silang patogen penyakit yang jalur penularannya melalui makanan. ${ }^{6}$
Lalat merupakan serangga pengganggu utama yang dapat membawa patogen pada tubuhnya. Permukaan tubuhnya yang dipenuhi dengan struktur rambut halus menjadi media pembawa yang baik bagi agen pathogen. ${ }^{7}$ Lalat sering berpindah-pindah ke tempat yang kotor untuk kemudian berpindah ke makanan atau tubuh manusia atau hewan. ${ }^{8}$

Lalat berperan dalam penyebaran penyakit seperti diare, disentri, kolera, demam tifoid dan paratifoid karena menyebarkan kotoran ke makanan, minuman, sayuran, buah-buahan, maupun ke tubuh ternak. ${ }^{9}$ Aktivitas lalat dipengaruhi oleh sinar, temperatur, kelembaban, air, makanan, dan tempat perindukan. Pada malam hari tidak aktif, kecuali bila ada sinar buatan. Lalat rumah berkembang biak pada zat organik seperti sampah, kotoran manusia dan hewan, sisa makanan, dan zat yang membusuk lainnya. ${ }^{10}$

Warna merupakan suatu upaya pengendalian serangga hama secara alternatif. Ketertarikan serangga terhadap warna adalah salah satu cara adaptasi serangga di alam. Adaptasi ini dapat terjadi pada serangga dengan tujuan melindungi dirinya dari gangguan predator. ${ }^{11}$ Fly Grill merupakan salah satu alat sederhana yang banyak digunakan dalam mengukur kapadatan lalat. Alat ini memiliki cara kerja yang sederhana dalam mengukur tingkat kepadatan lalat. ${ }^{12}$

Fly Grill dapat diwarnai dengan berbagai macam warna agar dalam pengukuran kepadatan lalat dengan varian warna pada Fly Grill bisa lebih baik dan lebih akurat dalam mengukur kepadatan lalat. ${ }^{13}$ Tujuan dalam penelitian ini yaitu untuk mengetahui pengaruh variasi warna pada Fly Grill terhadap kepadatan lalat (Studi di Rumah Pemotongan Ayam Pasar Terban Kota Yogyakarta). Hal ini dapat membantu masyarakat dalam memilih warna peralatan yang diperlukan dalam pengendalian kepadatan lalat, misalnya bak sampah atau perangkat lalat, sehingga populasi lalat dapat terkontrol sesuai yang direncanakan. Manfaat yang lebih luas adalah pemilihan warna tersebut dapat membantu pengendalian penyakit yang disebebkan karena lalat.

\section{MATERI DAN METODE}

Penelitian ini dilakasanakan di Rumah Pemotongan Ayam Pasar Terban Kota Yogyakarta. Jenis penelitian dalam penelitian ini adalah Kuantitatif dengan desain analitik eksperimental yakni dengan rancangan Kuasi eksperimen karena penelitian dan pengukuran dilakukan langsung di lapangan serta tidak dapat dilakukan pengendalian terhadap variabel penganggu secara penuh. Jenis penelitian ini 
kuantitatif dengan desain kuasi eksperimen menggunakan pendekatan post test only control group design, dimana dalam rancangan ini memungkinkan peneliti untuk mengukur pengaruh perlakuan (intervensi) pada kelompok eksperimental dengan cara kelompok tersebut dibandingkan dengan kelompok kontrol. ${ }^{14}$

Alat ukur/intrumen yang digunakan dalam penelitian ini adalah Fly Grill yang merupakan alat penghitung kepadatan lalat secara sederhana yang berbahan dasar bambu, stop watch, serta hand counter. Pengukuran kepadatan lalat menggunakan Fly Grill dengan lima warna berbeda. Titik pengukuran menggunkan tiga titik yaitu 0,1 dan 2 meter diukur dari tempat pemotongan ayam. Tiga titik ini sebagai ulangan. Dalam penelitian ini disediakan tiga Fly Grill untuk setiap warna, baik warna kuning, biru, hijau, putih dan kontrol (bambu tanpa diberi cat) untuk setiap titik $(0,1$ dan $2 \mathrm{~m})$.

Pada setiap titik dilakukan sepuluh kali pengukuran kepadatan lalat sesuai ketentuan umum penggunaan Fly Grill, baru kemudian diambil lima hasil pengukuran kepadatan lalat tertinggi dan diratarata untuk dilakukan uji statistik. Hasil kepadatan lalat berdasarkan pengukuran dibandingkan kemudian dikategorikan berdasarkan indeks kepadatan lalat. ${ }^{10}$ Teknik uji statistik yang digunakan adalah uji One Way ANOVA. Data yang diperoleh dalam penelitian ini terdistribusi normal, variasi sama $(\mathrm{p}>0,05)$ maka dilanjutkan dengan uji post hoc bonferroni.

\section{HASIL DAN PEMBAHASAN}

Dalam penelitian ini dilakukan pengukuran kepadatan lalat dengan menggunakan dengan metode Fly Grill. Hasil kepadatan lalat berdasarkan pengukuran dibandingkan kemudian dikategorikan berdasarkan indeks kepadatan lalat. ${ }^{10}$ Adapun hasil pengukuran jumlah lalat yang hinggap pada berbagai warna pada Fly Grill. Hasil pengukuran jumlah lalat yang hinggap pada berbagai warna pada Fly Grill setelah di rata-ratakan adalah sebagai berikut.

Tabel 1. Rata-Rata Kepadatan Lalat Setiap Titik Pada Setiap Warna Fly Grill di Rumah Pemotongan Ayam Pasar Terban Kota Yogyakarta Tahun 2018

\begin{tabular}{|c|c|c|c|c|}
\hline Warna & Titik Ukur & Hasil & Rata-Rata & Kategori \\
\hline \multirow[t]{3}{*}{ Kontrol } & 0 Meter & 9,4 & 7,06 & Tinggi/Padat \\
\hline & 1 Meter & 6,8 & & \\
\hline & 2 Meter & 5,0 & & \\
\hline \multirow[t]{3}{*}{ Kuning } & 0 Meter & 11,0 & 9,93 & Tinggi/Padat \\
\hline & 1 Meter & 11,6 & & \\
\hline & 2 Meter & 7,2 & & \\
\hline \multirow[t]{3}{*}{ Hijau } & 0 Meter & 10,6 & 8,4 & Tinggi/Padat \\
\hline & 1 Meter & 5,8 & & \\
\hline & 2 Meter & 8,8 & & \\
\hline \multirow[t]{3}{*}{ Biru } & 0 Meter & 4,4 & 3,6 & Sedang \\
\hline & 1 Meter & 3,0 & & \\
\hline & 2 Meter & 3,6 & & \\
\hline \multirow[t]{3}{*}{ Putih } & 0 Meter & 9,6 & 9,73 & Tinggi/Padat \\
\hline & 1 Meter & 8,2 & & \\
\hline & 2 Meter & 11,4 & & \\
\hline
\end{tabular}

Tabel 1. di atas menunjukkan hasil perhitungan kepadatan lalat di setiap warna pada tiga titik perhitungan, rata-rata kepadatan lalat tertinggi pada Fly Grill berwarna kuning dan kepadatan lalat terendah pada Fly Grill warna biru. Pada Fly Grill Warna Asli Bambu (Kontrol) diperoleh hasil akhir pengukuran rata-rata kepadatan lalat yaitu 7,06 dan termasuk ke dalam kategori tinggi/padat (6-20) yaitu perlu pengamanan tempat-tempat perkembangbiakan lalat dan bila mungkin direncanakan upaya pengendaliannya.

Penelitian ini sejalan dengan penelitian sebelumnya yakni pengaruh variasi warna Fly Grill dengan menggunakan warna ungu, coklat, hijau dan putih dimana warna coklat termasuk ke dalam kategori tinggi/padat, warna coklat disini hampir sama dengan warna asli bambu yang digunakan yakni warna coklat dengan menggunakan variasi warna Fly Grill. ${ }^{15}$

Lalat yang hinggap di Fly Grill warna asli bambu (Kontrol) lebih sedikit dibandingkan dengan lalat yang hinggap di Fly Grill kuning, putih, dan hijau, namun lebih tinggi dibandingkan dengan rata-rata kepadatan lalat pada Fly Grill warna biru.

Pada Fly Grill warna kuning di peroleh hasil akhir rata-rata 9,93 dan Termasuk dalam kategori tinggi/padat di angka (6-20). Penelitian ini sejalan dengan penelitian sebelumnya di Semarang, hasil pengukuran kepadatan lalat menggunakan Fly Grill didapatkan hasil warna kuning lebih mendominasi tingkat kepadatan lalat dibandingkan dengan warna lainnya. ${ }^{16}$ Penelitian lain dengan ada tentang pengaruh pemberian jus buah dan warna pada perangkap lalat buah. Hasil penelitian menunjukkan warna kuning yang dikombinasikan baik dengan jus 
belimbing maupun jus jambu biji memberikan hasil tangkapan yang tinggi daripada warna lainnya. ${ }^{17}$

Lalat yang hinggap di Fly Grill warna kuning paling banyak dibandingkan dengan lalat yang hinggap di Fly Grill warna bambu asli, putih, hijau, dan biru. Sehingga, warna kuning merupakan warna yang paling diminati oleh lalat.

Pada Fly Grill Hijau diperoleh hasil akhir rata-rata 8,4 termasuk ke dalam kategori tinggi/padat (6-20). Penelitian ini sejalan dengan peneliti sebelumnya yakni upaya pengendalian alternatif hama serangga dengan menggunakan warna yakni warna merah, kuning dan hijau, dengan menggunakan kertas perangkap pada siang hari dan lampu pada malam hari, didapatkan warna hijau termasuk kedalam kategori kepadatan lalat yang tinggi. ${ }^{18}$ Penelitian ini tidak sejalan dengan penelitian yang di lakukan di jambi dimana peneliti mencari pengaruh variasi warna Fly Grill dengan menggunakan warna ungu, coklat, hijau dan putih, diperoleh warna hijau menjadi warna terendah dihinggapi lalat dengan jumlah lalat yang hinggap 24 ekor. ${ }^{19}$

Tabel 1. di atas menunjukan Fly Grill warna hijau merupakan warna tertinggi ketiga setelah kuning dan putih dan lebih tinggi dibandingkan dengan warna bambu asli dan biru. Pada Fly Grill warna biru
Termasuk ke dalam kategori sedang (3-5) yang berarti perlu dilakukan penanganan terhadap tempat-tempat perkembangbiakan lalat seperti tumpukan sampah, kotoran hewan dan sebagainya.

Persamaan pada penelitian sebelumnya yakni penelitian sebelumnya menggunakan variasi warna Fly Grill dengan warna putih, coklat, asli kayu, hitam, merah, kuning dan biru, warna biru merupakan warna yang paling sedikit rerata kepadatan lalatnya $(5,33) .^{20}$ Penelitian ini tidak sejalan pada penelitian sebelumnya yakni dengan menggunakan variasi warna lampu pada alat perekat lalat, diperoleh hasil yang paling tinggi atau lampu yang paling efektif adalah lampu berwarna biru. ${ }^{21}$

Pada Fly Grill putih diperoleh rata-rata hasil akhir sebesar 9,73 yang termasuk ke dalam kategori tinggi/padat (6-20). Lalat yang hinggap di Fly Grill warna putih lebih sedikit dibandingkan dengan lalat yang hinggap di Fly Grill kuning, namun lebih tinggi dibandingkan dengan rata-rata kepadatan lalat pada Fly Grill warna bambu (kontrol), hijau, dan biru. Penelitian ini sejalan dengan penelitian sebelumnya, dimana peneliti menggunakan aroma umpan dan warna kertas perangkap lalat, diperoleh hasil warna yang banyak dihinggapi lalat adalah warna putih. ${ }^{22}$

Tabel 2. Hasil Uji ANOVA

\begin{tabular}{lccccc}
\hline & Sum of Square & Df & Mean Square & $\mathrm{f}$ & Sig \\
\hline Between Group & 78,789 & 4 & 19,697 & 5,042 & 0,017 \\
Within Group & 39,067 & 10 & 3,907 & & \\
$\quad$ Total & 117,856 & 14 & & & \\
\hline
\end{tabular}

Tabel 2 menunjukkan hasil uji one way anova pada variabel dependen. Sum of squares atau jumlah kuadrat dari deviasi masing-masing pengamatan menunjukkan nilai 78,789 untuk variansi antar kelompok sedangkan nilai 39,067 untuk variansi dalam kelompok. Derajat kebebasan antar kelompok berjumlah 4 sedangkan derajat kebebasan dalam kelompok berjumlah 10. Mean square atau rata-rata kuadrat antar kelompok menunjukkan nilai 19,697 sedangkan rata-rata kuadrat dalam kelompok menunjukkan nilai 3,907. F empiris pada penelitian ini bernilai 5,042 dan uji one way anova menunjukkan nilai 0,017 yang berarti signifikan $(0,017<0,05)$. Artinya ada perbedaan signifikan rata rata jumlah lalat yang terperangkap pada flygrill yang berbeda warna. Peneliti selanjutnya mencoba menggunakan Multiple comparison melalui post hoc benferroni test. Hal ini dilakukan untuk dapat mengetahui warna flygrill yang memiliki beda nyata terhadap rata rata jumlah lalat yang terperangkap.

Tabel 3. Hasil Uji Perbedaan Warna Pada Fly Grill Terhadap Kepadatan Lalat Di Rumah Pemotongan Ayam Pasar Terban Kota Yogyakarta Tahun 2018

\begin{tabular}{|c|c|c|c|c|c|}
\hline Perlakukan & Kontrol & Kuning & Hijau & Biru & Putih \\
\hline Kontrol & - & 1,000 & 1,000 & 0,614 & 1,000 \\
\hline Kuning & & - & 1,000 & $0,030^{*}$ & 1,000 \\
\hline Hijau & & & - & 0,150 & 1,000 \\
\hline Biru & & & & - & $0,037^{*}$ \\
\hline Putih & & & & & - \\
\hline
\end{tabular}

Tabel 3 menunjukkan hasil pengujian terhadap dua kelompok penelitian. Perbedaan rata-rata variasi Warna Pada Fly Grill dibandingkan dengan kepadatan lalat. Dari hasil uji statistik post hoc ntuk mengetahui perbedaan variasi warna pada Fly Grill warna Kuning, hijau, biru, putih dan warna asli bambu (kontrol), lalu didapatkan hasil antara Fly Grill warna kuning- Fly Grill warna biru diperoleh nilai p value $0,030<\alpha(0,05)$, 
artinya terdapat perbedaan yang bermakna antara Fly Grill warna kuning dan Fly Grill biru. Serta hasil antara Fly Grill warna biru- Fly Grill warna putih diperoleh nilai $\mathrm{p}$ value $0,037<\alpha(0,05)$, artinya terdapat perbedaan yang bermakna antara Fly Grill warna biru dan Fly Grill putih. Maka dapat disimpulkan bahwa "terdapat perbedaan kepadatan lalat pada Fly Grill warna Kuning-Biru dan Fly Grill warna biru-putih di Rumah Pemotongan Ayam (RPA) Pasar Terban Kota Yogyakarta. Hasil rata-rata kepadatan lalat di Rumah Pemotongan Ayam Pasar Terban Yogyakarta menunjukan warna biru mempunyai kepadatan yang paling kecil. Sehingga dapat disimpulkan bahwa warna biru merupakan warna yang paling tidak disukai oleh lalat.

Respon lalat pada rangsangan penglihatan tergantung warna, bentuk dan ukuran. Banyaknya jumlah lalat yang terdapat di setiap Fly Grill dapat menentukan ketertarikan lalat dalam memilih tempat untuk hinggap. ${ }^{16}$ Kombiasi warna mempengaruhi kunjungan lalat, diduga lalat hanya menyukai warna yang cerah dan tidak menyukai warna yang gelap. Warna gelap kurang berpegaruh terhadap padangan mata serangga. ${ }^{23}$ Penelitian lain mnyatakan bahwa salah satu sifat lalat yang terpenting adalah takut dengan warna biru. Hal ini masih menjadi perdebatan, namun diduga intensitas sinar yang tinggi (kuat) lebih mudah ditangkap oleh mata serangga (lalat). Warna putih dan kuning memiliki intensitas yang lebih tinggi dibanding hijau dan biru, sehingga lebih mudah dikenali lalat untuk dihinggapi. ${ }^{22}$

Hasil penelitian menunjukan warna yang paling disenangi lalat adalah warna kuning, lalat peka terhadap warna kuning. Oleh karena itu, warna kuning merupakan warna kesukaan lalat, dan serangga pada umumnya. Penelitian sebelumnya yakni pengaruh warna dan volume Atraltan terhadap lalat buah belimbing, hasil yang didapat yakni jumlah lalat yang terperangkap pada botol warna kuning. ${ }^{24}$ Penelitian lain perangkap basah pada pengendalian lalat buah dengan menggunakan warna kuning, biru, hijau, merah, hitam dan tanpa warna, hasil yang di dapatkan warna kuning menjadi warna yang paling tinggi (paling menarik lalat) dengan jumlah lalat terperangkap sebesar $27,69 \%{ }^{25}$

Secara teori lalat dapat mengenali warna. Indera penglihatan serangga (termasuk lalat) ada 3 macam, yaitu kulit, mata ocelli, dan mata facet (mata majemuk). Bias sinar dari benda ditangkap oleh omatidum (bagian mata facet) dan diteruskan ke retina dan masuk otak serangga. Pancaran warna yang kuat (kuning) paling mudah dikenali oleh serangga. ${ }^{26}$

Lalat bergantung pada sinar matahari untuk mendeteksi objek di lingkungannya ketika terbang, mencari makanan, dan mencari tempat peristirahatan. Infomasi visual dari komponen mata dan oceli lalat mungkin berintegrasi untuk membentuk impuls sensorik yang mempengaruhi bionomik lalat dalam merespon refleksi cahaya dari suatu objek. ${ }^{22}$ Studi tentang fotoreseptor pada komponen mata lalat rumah menyebutkan terdapatnya 3 puncak kepekaan cahaya, yaitu pada panjang gelombang $490 \mathrm{~nm}$ (biru/hijau), $570 \mathrm{~nm}$ (kuning), dan pada rentang panjang gelombang ultraviolet yaitu $330-350 \mathrm{~nm} .{ }^{27}$

Kepadatan dan penyebaran lalat sangat dipengaruhi oleh reaksi terhadap cahaya, suhu dan kelembaban udara, serta warna dan tekstur permukaan tempat. Warna kuning dan putih adalah warna yang bisa dan mudah dikenali oleh serangga. Hal ini lah yang menyebabkan lalat lebih tertarik pada warna tersebut. Infomasi visual dari komponen mata dan oceli lalat mungkin berintegrasi untuk membentuk impuls sensorik terhadap warna kuning atau putih yang mempengaruhi bionomik lalat dalam merespon refleksi cahaya sehingga mudah dikenali oleh serangga.

\section{SIMPULAN}

Hasil menunjukkan ada perbedaan kepadatan lalat pada Fly Grill warna Putih, Kuning, Biru, Hijau, dan Kontrol di Rumah Pemotongan Ayam Pasar Terban Kota Yogyakarta. Terdapat perbedaan yang bermakna pada kepatan lalat Fly Grill warna kuningbiru dan Fly Grill warna biru-putih. Warna kuning merupakan warna dengan kepadatan lalat paling tinggi, sedangkan warna biru merupakan warna yang paling rendah kepadatan lalatnya. Yang paling disukai lalat adalah warna kuning, dan paling tidak disukai lalat adalah warna biru.

\section{DAFTAR PUSTAKA}

1. Peraturan Pemerintah No. 66 Tahun 2014 tentang Kesehatan Lingkungan. Meliputi Baku Mutu Kesehatan Lingkungan.

2. Listya N, Sukmawati, Ginandjar P, Hestiningsih R. Keanekaragamaan Spesies Lalat di Rumah Pemotongan Unggas (RPU) Semarang. Jurnal Kesehatan Masyarakat. 2018;7(1):252-259.

3. M Achmy R, Oktiawan, Wardhana IW. Pengolahan Limbah Rumah Pemotongan Hewan (RPH) Menjadi Pupuk Cair Yang Diperkaya Dengan Unsur Magnesium (Mg) Yang Berasal Dari Limbah Garam (Bittern). Jurnal Teknik Lingkungan. 2015; 4(3):1-10.

4. Masyhuda, Hastiningsih R, Rahadian R. Survei Kepadatan Lalat di Tempat Pembuangan Akhir (TPA) Sampah Jatibarang Tahun 2017. Jurnal Kesehatan Masyarakat. 2017;5(4):560-569.

5. Wahyudi P, Soviana S, Hadi UK. Keragaman Jenis dan Prevalensi Lalat Pasar Tradisional di Kota Bogor. Jurnal Veteriner. 2015;16(4):474-482.

6. De Jesus AJ, Olsen AR, Bryce JR, Whiting RC. Quantitative Contamination and Transfer of Escherichia coli from Foods by Houseflies, Musca domestica L. (Diptera: muscidae). International Journal of Food Microbiology. 2004. 93(2): 259262.

7. Andiarsa D, Setianingsih I, Fadilly A, Hidayat S, Setyaningtyas DE, Hairani B. Gambaran Bakteriologis Lalat dan Culicidae (Ordo: Diptera) 
di Lingkungan Balai Litbang P2B2 Tanah Bumbu. Jurnal Vektor Penyakit. 2015;9(2): 37-44.

8. Malik A, Singh N, Satya S. House fly (Musca domestica): A review of control strategies for a challenging pest. Journal of Environmental Science and Health, Part B: Pesticides, Food Contaminants, and Agricultural Wastes. 2007;42(4):453-469.

9. Ihsan IM, Hidayati R, Hadi UK. Pengaruh Suhu Udara terhadap Fekunditas Dan Perkembangan Pradewasa Lalat Rumah (Musca Domestica). Jurnal Teknologi Lingkungan. 2016;17(2):100107.

10. Departemen Kesehatan RI. Petunjuk Teknis Tentang Pemberantasan Lalat. Jakarta: Ditijen PP/PLP; 1992.

11. Sihombing SW, P Yuswani UT, Mena. Perangkap Warna Perekat Terhadap Hama Capside (Cyrtopeltis tenuis Reut) (Hemiptera: Miridae) Pada Tanaman Tembakau. Jurnal Agroteknologi. 2013;1(4):1352-1359.

12. Nadeak ESM, Rwanda T, Iskandar I. Efektifitas Variasi Umpan Dalam Penggunaan Fly Trap Di Tempat Pembuangan Akhir Ganet Kota Tanjungpinang. Jurnal Kesehatan Masyarakat Andalas. 2015;10(1):82-86.

13. Inayah Z, Hermanta, Fidayanti D. Perbedaan Kepadatan Lalat Yang Hinggap Pada Fly Grill Yang Berbeda Warna di Pasar Srimangunan. Jurnal Kesmas.2012;4(1).

14. Dahlan, MS. Statistik Untuk Kedokteran Dan Kesehatan. Seri 1, edisi 6. Jakarta: Epidemiologi Indonesia; 2014.

15. Ariyani A S, Munawar A. Pengaruh Warna Fly Grill Terhadap Kepadatan Lalat Di TPA Talang Gulo Kota Jambi Tahun 2014. Jurnal Bahan Kesehatan Masyarakat. 2014;2(1):62-67.

16. Wulandari DA. Pengaruh Variasi Warna Kuning Pada Fly Grill Terhadap Kepadatan Lalat (Studi di Tempat Pelelangan Ikan Tambak Lorok Kota Semarang). Jurnal Kesehatan Masyarakat.2015;3(3):130-141.

17. Kumbara AM, Swibawa IG, Hariri AM, Hasibuan R. Pengaruh Pemberian Juas Buah Terhadap Jumlah Tangkapan Lalat Buah Dan Serangga Lain Pada Pertanaman Cabai Merah. Jurnal Jurusan agroteknik. 2018;6(2):78-85.
18. Hakim L, Surya E, Muis A. Pengendalian Alternatif Hama Serangga Sayuran Dengan Menggunakan Warna Sebagai Perangkap Mekanis. Jurnal Serambi Saintia. 2017;V(1): 1-12.

19. Ariyani A S, Munawar A. Pengaruh Warna Fly Grill Terhadap Kepadatan Lalat Di TPA Talang Gulo Kota Jambi Tahun 2014. Jurnal Bahan Kesehatan Masyarakat. 2014;2(1):62-67.

20. Husain SE, Kadir S, Boekoesoe L. Pengaruh Variaso Warna Fly Grill Terhadap Kepadatan Lalat Di Tempat Pelelangan Ikan (TPI) Kota Gorontalo. Gorontalo Universitas Negeri Gorontalo.

21. Prasetya RD, Yamtana, Amalia R. Pengaruh Variasi Warna Lampu Pada Alat Perekat Lalat Terhadap Jumlah Lalat Rumah (Musca Domestica) Yang Terperangkap. Jurnal BALABA. 2015;11(1):29-34.

22. Sayono, Mardhotillah S, Martini. Pengaruh Aroma Umpan Dan Warna Kertas Perangkap Terhadap Jumlah Lalat Yang Terperangkap. Jurnal litbang. 2005;2(2):30-36.

22. Mardhotillah S. Pengaruh Warna Kertas Pada Perangkap Lalat. Jurnal Litbang. 2012;25(23):13.

23. Jumar. Entomologi Pertanian. Jakarta: Rineka Cipta; 2000.

24. Sodiq M, Sudarmadji, Sutoyo. Pengaruh Warna dan Volume Tempat Atraltan Terhadap Lalat Buah Belimbing di Kecamatan Alang, Tuban Jawa Timur. Jurnal Plumuta. 2016;5(2):1-6.

25. Syofia I, Nursamsi, Indrian H. Efektifitas Beberapa Warna Perangkap Basah Untuk Mengendalikan Hama Lalat Buah (Bactrocera Sp) Pada Tanaman Belimbing. Jurnal Agrium. 2012;17(3):182-185.

26. Diclaro JW, Cohnstaedt LW. Pereira RM, Allan SA, Koehler PG. Behavioral and Physiological Response of Musca domestica to Colored Visual Targets. Journal of Medical Entomology.2012;49(1):94-100.

27. Hanley ME, Cruickshanks KL, Dunn DD, Stewart-Jones A, Goulson D. Luring Houseflies (Musca domestica) to Traps: Do Cuticular Hydrocarbons and Visual Cues Increase Catchs?. Medical and Veterinary Entomology Journal.2008;23(1):26-33. 